\title{
CONTRIBUTION OF MOSCOW UNIVERSITY TO THE DEVELOPMENT OF SCHOOLS IN THE MOSCOW SCHOOL DISTRICT IN THE EARLY $19^{\text {th }}$ CENTURY $^{1}$
}

\author{
Julija E. Gracheva \\ St. Tikhon's Orthodox University, Moscow, Russian Federation
}

\begin{abstract}
Introduction. The article explores the role of Moscow University in the formation and development of secondary and primary education institutions. One of the main means of university control of schools was a number of professors' visits. Methods and materials. The author applies the principles of historicism, objectivity and consistency. For the first time, systematic reports from visitors and reports of trustees of the Moscow school district for the period 1803-1811 stored in the Russian State Historical Archive are used as the main sources for the history of visits. Analysis. Inspection of high schools and district schools of the district was carried out by professors annually. Visitors were appointed by the University Council at the suggestion of the trustee. The main purpose of such trips was to control the economic and education life of schools. After return, they provided the university authorities with review journals, on the basis of which school officials were awarded or dismissed. The visitors were present as deputies from the university at solemn celebrations dedicated to opening or transforming education institutions. According to the visitors, the main obstacle to increasing the number of education institutions in the Moscow school district was the unsatisfactory condition of a large part of school houses and the lack of capable teachers. This slowed down the pace of converting small public schools into county schools and required additional funds and donations from the local population. Results. Analysis of visitor reports allows us to prove that the professors were attentive to the tasks set for them, tried to visit every education institution located in the provinces they inspected. Visiting trips attracted the attention of the provincial and district authorities, as well as local residents to the needs of education institutions.
\end{abstract}

Key words: Moscow University, visitations, educational district, gymnasium, county school, visitor reports.

Citation. Gracheva Ju.E. Contribution of Moscow University to the Development of Schools in the Moscow School District in the Early $19^{\text {th }}$ Century. Vestnik Volgogradskogo gosudarstvennogo universiteta. Seriya 4. Istoriya. Regionovedenie. Mezhdunarodnye otnosheniya [Science Journal of Volgograd State University. History. Area Studies. International Relations], 2020, vol. 25, no. 2, pp. 56-67. (in Russian). DOI: https://doi.org/10.15688/ jvolsu4.2020.2.4

Дата поступления статьи: 30.11.2019

ББК 63.3(2)521

Дата принятия статьи: 06.03.2020

\section{ВКЛАД МОСКОВСКОГО УНИВЕРСИТЕТА В РАЗВИТИЕ УЧИЛИЩ МОСКОВСКОГО УЧЕБНОГО ОКРУГА В НАЧАЛЕ ХІХ ВЕКА ${ }^{1}$}

\footnotetext{
Юлия Евгеньевна Грачева

Православный Свято-Тихоновский гуманитарный университет, г. Москва, Российская Федерация

Аннотация. Введение. В статье исследуется роль Московского университета в становлении и развитии средних и начальных учебных заведений. Одним из основных средств контроля университета над училищами стали визитаторские поездки профессоров. Memoды u материаль. При написании статьи применены принципы историзма, объективности и системности. В качестве основных источников по истории визитаций впервые используются систематические донесения визитаторов и отчеты попечителей Московского учебного округа за период 1803-1811 гг, хранящиеся в Российском государственном исто-
} 
рическом архиве. Анализ. Осмотр гимназий и уездных училищ округа осуществлялся профессорами ежегодно. Визитаторы назначались Советом университета по предложению попечителя. Главной целью подобных поездок являлся контроль за хозяйственной и учебной жизнью училищ. После возвращения они предоставляли университетскому начальству журналы обозрений, на основании которых шло награждение или увольнение училищных чиновников. Визитаторы присутствовали в качестве депутатов от университета на торжественных праздниках, посвященных открытию или преобразованию учебных заведений. По мнению визитаторов, главным препятствием к увеличению числа учебных заведений в Московском учебном округе являлось неудовлетворительное состояние значительной части училищных домов и недостаток способных учителей. Это замедляло темпы преобразования малых народных училищ в уездные и требовало дополнительных денежных средств и пожертвований местного населения. Результаты. Анализ визитаторских отчетов позволяет доказать, что профессора внимательно относились к поставленным перед ними задачам, старались посетить все учебные заведения, находящиеся в инспектируемых ими губерниях. Визитаторские поездки привлекали внимание губернского и уездного начальства, а также местных жителей к нуждам учебных заведений.

Ключевые слова: Московский университет, визитации, учебный округ, гимназия, уездное училище, визитаторские отчеты.

Цитирование. Грачева Ю. Е. Вклад Московского университета в развитие училищ Московского учебного округа в начале XIX века // Вестник Волгоградского государственного университета. Серия 4, История. Регионоведение. Международные отношения. - 2020. - Т. 25, № 2. - С. 56-67.-DOI: https://doi.org/10.15688/jvolsu4.2020.2.4

Введение. 24 января 1803 г. императором Александром I были утверждены «Предварительные правила народного просвещения», согласно которым в Российской империи «для нравственного образования граждан соответственно обязанностям и пользам каждого состояния» [18, с. 14] учреждалась четырехступенчатая система учебных заведений - приходское училище, уездное училище, гимназия и университет. Последний становился центром учебного округа и должен был контролировать состояние всех учебных заведений, входящих в его состав. Помимо получения письменных донесений от директоров гимназий, университету поручалось ежегодно отправлять профессоров для личного контроля учебного процесса в училищах своего округа. Стоит отметить, что таким обозрениям придавалось особое значение: объезжать учебные заведения должны были не реже одного раза в два года и попечители учебных округов [3]. Конечно, не все попечители могли систематически совершать такие поездки, но они старались следить за тем, чтобы университетские визитации были регулярными. Появление в уездных городах университетских профессоров и личное пристальное внимание к учебному процессу в средних и начальных училищах должны были стать толчком для развития образовательной среды округа, способствовать увеличению интереса местных жителей к школам, распространению обще- ственной инициативы и добровольных пожертвований и, как следствие, привести к увеличению количества учебных заведений и учащихся в них. Цель данной статьи - анализ визитаторских поездок профессоров Московского университета в начале XIX в., что позволит ответить на ряд важных вопросов: действительно ли внимание университетских преподавателей способствовало развитию сети учебных заведений в округе, являлись ли данные поездки формальной обязанностью для профессоров и насколько подробно мог проходить осмотр училищ?

Методы и материалы. Статья написана на основе привлечения и комплексного анализа всей совокупности сохранившихся визитаторских донесений профессоров Московского университета и отчетов попечителей Московского учебного округа за 1803-1811 гг, значительная часть которых вводится в научный оборот впервые. В ходе исследования применены принципы историзма, объективности и системности, что позволяет провести анализ визитаторских поездок профессоров Московского университета и выявить их влияние на развитие училищ округа.

Вопрос о необходимости и целесообразности иерархической зависимости гимназий и уездных училищ от университета в российской историографии был поставлен еще во 2-й половине XIX века. По мнению профессора Петербургского университета 
М.И. Сухомлинова, «Главное Правление училищ руководствовалось той мыслью, что университеты должны служить рассадником просвещения, вызвать к жизни всю массу училищ и повести их по пути распространения знаний. Внутренняя сила университетов, их устройство и направление неминуемо должно было отразиться на всей системе создаваемых и руководимых ими училищ» [22, с. 117]. Крупнейший дореволюционный специалист в области народного просвещения С.В. Рождественский отмечал, что, «подчинив директоров гимназий университетам, смотрителей уездных училищ губернским директорам», Устав 1804 г. предоставил учебной администрации «необходимую ей сосредоточенность и независимость» $[19$, с. 64$]$. Однако изучение реального вклада университета в процесс становления и развития средних и начальных учебных заведений затрагивался в научной литературе достаточно фрагментарно [9, с. 482-488; 23, c. 221-223]. Внимание современных ученых в основном сосредоточено на деятельности Петербургского университета и его роли в системе управления подведомственными учебными заведениями [4; 5]. Подобных работ на материале Московского учебного округа в литературе нет, что объясняет актуальность проведенного исследования.

Анализ. Первым попечителем Московского учебного округа 24 января 1803 г. стал тайный советник, товарищ министра народного просвещения Михаил Никитич Муравьев, которого современные исследователи считают одной из самых замечательных фигур начала александровского царствования [2, с. 44]. Наряду с остальными членами Главного правления училищ, М.Н. Муравьев принимал участие в составлении основополагающих документов, определивших устройство всех учебных заведений в России, - «Предварительных правил народного просвещения», университетского устава и «Устава учебных заведений, подведомых университетам». Одним из главных принципов образовательной реформы императора Александра I стало создание единой системы образовательных учреждений и установление иерархической зависимости низших училищ от высших. Таким образом, Московский университет как центр одноименного учебно- го округа должен был контролировать деятельность гимназий, уездных и приходских училищ, располагавшихся на территории Московской, Владимирской, Смоленской, Вологодской, Калужской, Тульской, Рязанской, Костромской, Тверской и Ярославской губерний.

Для того чтобы ознакомиться с положением дел в округе, узнать о точном количестве и состоянии учебных заведений, каждый попечитель должен был отправить для совершения личного обозрения нескольких профессоров-визитаторов. Уже в конце апреля 1803 г. попечитель Виленского университета кн. А.А. Чарторыйский представил на утверждение министра народного просвещения гр. П.В. Завадовского наставление для визитаторов, найденное «весьма достойным и предмету сего звания соответственным» [17, c. 216]. На основе этого текста М.Н. Муравьев подготовил свой вариант наставлений, который отправил в письме ректору Московского университета Х.А. Чеботареву [8, л. 44].

Сохранившаяся инструкция достаточно подробно раскрывает задачи, стоявшие перед университетскими преподавателями в ходе ежегодных объездов. Визитаторы были обязаны лично проверять имеющуюся информацию о состоянии каждого учебного заведения: в каком здании находится, удобно ли оно для проведения занятий, достаточно ли имеет учебных пособий и вспомогательных материалов. Обязательное присутствие на открытых испытаниях должно было дать визитатору понимание степени успешности учебного процесса в училище. В наставлении подчеркивалось, что «каждый класс должен быть испытан подробно и с довольным временем, дабы обозритель мог удовлетвориться о действительных успехах каждаго, не останавливаяся на тех единственно, которые от учителей признаются отличными, и которые не могут служить общею мерою успехов» [11, л. 59 об.], причем главным качеством ответа ученика стоило считать не механическое повторение заученного материала, а понимание и практическое применение преподанных знаний. Наиболее способных учеников следовало поощрять наградами, «представляя им новую дорогу в усовершенствовании их знаний в вышних училищах» [11, л. 59 об.]. Отдельно визитатор дол- 
жен был оценить уровень преподавания и способности учителей.

Все данные, полученные в ходе осмотра училищ, свои замечания, рассуждения и предложения визитатор заносил в журнал обозрения. По возвращении в университет этот журнал представлялся на обсуждение в Училищный комитет, который в свою очередь делал из всех визитаторских донесений общее систематическое изложение (более или менее краткое) и через Совет университета посылал на утверждение попечителю [24, с. 327]. Таким образом, наиболее подробная информация о визитации содержалась именно в журналах обозрения. К сожалению, в ходе московского пожара 1812 г. почти весь корпус документов, находившийся в архиве университетской канцелярии, был уничтожен. Единственный сохранившийся журнал обозрения принадлежит перу профессора А.А. Прокоповича-Антонского, осматривавшего училища Рязанской и Владимирской губерний в 1805 году. Визитаторский журнал был найден среди других бумаг профессора и частично опубликован в 1888 г. в «Трудах Рязанской ученой архивной комиссии» [14]. Систематические извлечения из визитаторских замечаний сохранились в ежегодных отчетах попечителя Московского учебного округа [15].

По предложению попечителя визитаторами на 1803 г. были назначены профессора М.И. Панкевич, И.А. Гейм, В.К. Аршеневский и коллежские асессоры М.И. Невзоров и П.М. Дружинин [8, л. 38]. Каждый из них должен был осмотреть учебные заведения двух губерний, однако, когда пришло время начинать визитацию, профессор В.К. Аршеневский по неизвестным причинам отказался. Таким образом, М.И. Панкевичу достались училища Ярославской, Вологодской и Костромской губерний, И.А. Гейму - Тульской и Калужской, М.И. Невзорову - Тверской и Смоленской, а П.М. Дружинину - Владимирской, Московской и Рязанской $[12$, л. 16 об.]. Самым оптимальным временем для такого путешествия был признан август: в гимназиях и уездных училищах с 1 августа начинались занятия, тогда как в университете до середины месяца продолжались каникулы. На содержание визитаторов и путевые издержки полагалась штатная сумма в 3000 руб. [8, л. 10].
В результате первого обозрения училищ визитаторы пришли к определенным выводам. Жители всех губерний Московского округа «более или менее наклонны к учению», однако существующий «образ учения в народных училищах постановленный» вынуждал родителей обучать своих детей дома. Необходимо было не только улучшить преподавание в училищах, но и увеличить их число, поскольку «самых заведений сих весьма недостаточно: из 138 городов, посадов и знатнейших сел в Московском учебном округе, народные училища имеются только в 83-х городах и одном посаде, не исключая и самой Москвы» [12, л. 18 об.]. Визитаторы обратили внимание и на занятия жителей отдельных губерний, отметив, что в программу обучения стоило бы ввести предметы, способствующие улучшению местных промыслов. Однако главное препятствие к развитию просвещения визитаторы видели в недостаточном финансовом и материальном обеспечении учебных заведений. «Когда благонравие учителей, впрочем хотя и не имеющих высоких знаний, соединится с удобностию училищных домов и избытком учебных пособий; то можно твердо надеяться, что народные училища легко преодолеют действие невежества, разрушат предрассудки и произведут желаемый успех в просвещении» [12, л. 19]. Стоит отметить, что недостаток учителей и удобных помещений для училищ останутся надолго главными проблемами, тормозящими развитие образовательных реформ. По визитаторским журналам в Училищном комитете было подготовлено два списка учителей: в одном из них перечислялись учителя, которые получили одобрение за свои знания и примерное поведение, а во втором - те, кто получил неодобрительный отзыв за предосудительное поведение и нерадение к должности. Список отличившихся учителей был опубликован в ближайшем номере «Периодического сочинения о успехах народного просвещения» [16, с. 66-68].

1804 г. стал важным этапом в развитии учебных заведений Московского округа. Все десять главных народных училищ округа было запланировано преобразовать в гимназии, даже несмотря на то, что детали училищного устава только обсуждались в Главном правлении училищ (он будет подписан 5 ноября 
1804 г.). Первыми были преобразованы Московская (2 января), Тверская (2 февраля) и Смоленская (26 марта) гимназии. Начиная с мая попечитель постоянно торопил ректора с очередным отправлением визитаторов, которые, по мысли М.Н. Муравьева, должны были не только совершить запланированный объезд, но и стать депутатами от университета в ходе открытия губернских гимназий. Так, професcop М.М. Снегирев присутствовал 7 августа на торжественном открытии Владимирской гимназии. Вологодская гимназия была преобразована 18 августа, а Костромская - 15 сентября в присутствии профессора Н.Е. Черепанова, а адъюнкт Н.Г. Щеголев оставил интересные замечания об открытии Тульской (4 августа) и Калужской (30 августа) гимназий. Последней в 1804 г. была преобразована Рязанская гимназия (27 ноября), куда был отправлен адъюнкт П.М. Дружинин. Поощряя преобразование учебных заведений в округе, попечитель рассчитывал на значительное увеличение интереса к новым училищам в обществе и, как следствие, на увеличение числа учащихся в них. Ведь, в отличие от школ, созданных при Екатерине II, обязанность содержания и заботы о материальном благосостоянии которых возлагались на приказы общественного призрения и городские думы, что не гарантировало стабильного поступления денег, новые же гимназии и уездные училища финансировались государством. Таким образом, уже в 1804 г. девять из десяти гимназий Московского учебного округа начали получать государственное содержание из казны, которое поступало через ведомство Министерства народного просвещения напрямую.

Появление гимназий в губернских городах способствовало открытию там и уездных училищ, которые формировались из первого и второго классов главного народного училища (тогда как третий и четвертый классы главного народного училища становились двумя низшими классами гимназии, к которым добавлялись два высших класса) [1, c. 28]. Значительный рост числа уездных училищ в Московском округе приходится на 1805-1806 гг.: по данным отчетов министра и попечителя, в 1804 г. в округе насчитывалось 8 уездных училищ; в 1805 г. - уже 34, а в 1806 г. - 41. Однако впоследствии динами- ка преобразований сильно замедлилась, и к 1812 г. из 116 уездных городов Московского учебного округа, в каждом из которых, согласно «Предварительным правилам народного просвещения», должно было находиться уездное училище, преобразовано оказалось лишь 47 школ. По мнению исследователей, «значительным препятствием к преобразованию малых народных училищ в уездные являлся недостаток учительских кадров, а также отсутствие достойных кандидатов на должности смотрителей уездных училищ и нехватка финансовых средств» [6, c. 79]. Несмотря на то что уездные училища по штату должны были получать от 1250 до 1600 руб. в зависимости от разряда, полностью переложить их содержание на казну не получилось. На приказы общественного призрения было возложено хозяйственное обеспечение этих учебных заведений, и в первую очередь поддержание в достойном состоянии училищных зданий. А это, как показывают визитаторские отчеты, оказалось тяжелой обязанностью.

В июне 1805 г. М.Н. Муравьев вновь напоминает Совету университета о «немедленном назначении особливых обозрителей... дабы они могли вступить в путь свой при самом начале времени отдохновения от университетских учений» [7, л. 92 об. - 93]. Для «соблюдения большей важности» попечитель предлагал отправить только ординарных профессоров, которые могли взять с собой по одному казенному студенту. Совет назначил для обозрения Рязанской, Владимирской и части Московской губерний профессора А.А. Прокоповича-Антонского; Вологодской губернии - профессора А.М. Брянцева; Смоленской и Тверской губерний - профессора И.А. Гейма; Ярославской и Костромской губерний - профессора В.К. Аршеневского; Калужской, Тульской и оставшейся части Московской губерний - профессора П.А. Сохацкого, а учебные заведения в Москве должны были посетить сразу четыре профессора - М.И. Панкевич, И.Т. Буле, Ф.Х. Рейнгард и Л.А. Цветаев. Часть тверских училищ было предложено осмотреть начальнику университетской типографии М.И. Невзорову, который как раз возвращался в Москву из столицы. К середине июля выбор Совета 
был одобрен попечителем, настоятельно просившим профессоров начать визитацию уже в конце месяца.

В последующие годы училища Московского учебного округа осматривали профессора И.А. Иде, Ф. Гольдбах, Х.Л. Штельцер, И.П. Воинов, А.М. Брянцев, Х.А. Шлецер, И.А. Двигубский, М.Г. Гаврилов, А.Ф. Мерзляков, М.Т. Каченовский. Каждый из них объезжал учебные заведения одной или двух губерний, стараясь посетить все имеющиеся училища - гимназию, уездные, приходские и малые народные. Интересно, что повторную визитацию в эти же губернии профессора не совершали: Совет университета предпочитал каждый год менять визитаторов (см. приложение).

В связи с принятием нового училищного устава Совет решил дополнить инструкцию для визитаторов, написанную М.Н. Муравьевым. На них теперь возлагалась обязанность проверять приходно-расходные книги гимназий и уездных училищ, следить за правильным хранением денежных средств, «в особенности, с какою пользою для училищ отдаются в сохранение остающиеся, если где есть, от обыкновенных расходов» [10, л. 10 об.]. Визитатор должен был склонять местное начальство к открытию училищ в тех уездах, где их еще не было, и если не уездных, то хотя бы приходских, «дабы заблаговременно приуготовить учеников к уездному» [10, л. 9 об.]. Ему давалось право от имени университета обращаться к гражданскому губернатору, требуя от него содействия и активной поддержки в этом вопросе. В отличие от высших и средних учебных заведений, получавших штатное содержание, приходские училища не финансировались государством. В городах они содержались за счет городских обществ, в казенных селениях - за счет прихожан, а в помещичьих - находились на содержании помещика $[25$, с. 366$]$. В связи с этим так важно было убедить местных жителей в необходимости заведения начальных школ и склонить их к пожертвованиям. Учителями для них могли стать священнослужители, поэтому визитатор должен был постараться «изобресть случай познакомиться с духовными властями и предрасположить их в пользу приходских училищ» $[10$, л. 13].
Профессора старались в точности выполнять предписанные наставления. Приезжая в губернский или уездный город, они первым делом осматривали здание, в котором помещалось учебное заведение. Затем проводилась проверка хозяйственной части гимназий и уездных училищ - финансовых отчетов, шнуровых книг, наличной суммы. Визитаторы осматривали библиотеки, физические и минеральные кабинеты (были только в гимназиях), проверяли наличие учебной литературы. В присутствии городничего, уездного предводителя дворянства, почетных горожан проводились открытые испытания, по результатам которых лучшие ученики награждались книгами. Отдельно профессора оценивали способности учителей, методику преподавания, отмечали их личные качества.

Университетский Устав 1804 г. налагал на университет обязанность не только получать все донесения директоров гимназий, требовать от них в случае какого-либо беспорядка нужные объяснения, но и назначать и увольнять, «если окажутся недостойными сего звания», всех училищных чиновников - губернских директоров, смотрителей училищ, учителей [24, с. 326-327]. Поэтому так важно было на месте убедиться в правильной постановке учебного процесса, в достаточном хозяйственном обеспечении училищ, что в первую очередь зависело от усердия директора училищ. Как правило, директора удостаивались от визитаторов похвальных оценок. Так, например, о директоре ярославских училищ было сказано, что он «любим в городе и попечителен» [20, л. 91], о тверском директоре - что он «рачителен к должности, а по поведению своему любим, уважаем всею публикою» [20, л. 99 об.], директор московских училищ «проходит звание свое с усердием и похвалою» [21, л. 154], подобная характеристика была дана и директору тульских училищ [21, л. 159]. Отрицательные же отзывы визитаторов могли стать причиной увольнения. Директор училищ Калужской губернии О.Г. Потресов, по донесению профессора М.И. Панкевича, «очевидно и кажется безвозвратно ослаб, частию по преклонности лет, а частию от нетрезвой жизни и непреодолимой уже привычки к оной» [21, л. 156 об.]. Директор училищ Вологодской губернии К.С. Станиславский не только ни разу 
за девять лет нахождения в должности не осматривал уездных учебных заведений (что входило в его обязанности), но и был заподозрен университетом в нерациональном расходовании казенных средств. Директор училищ не позволил осмотреть профессору М.М. Снегиреву денежную казну, «удерживал еще, не известно для чего, знатную в руках своих сумму училищам принадлежащую тогда, когда бы она могла приносить пользу», а вместо наличных денег представил визитатору расписку «в том виде, как бы сумма сия взята была им на расходы по училищам» [21, л. 161 об.]. На следующий год и О.Г. Потресов, и К.С. Станиславский лишились своих мест.

При осмотре училищ визитаторы обращали внимание на соответствие преподаваемых предметов уставу учебных заведений, поскольку даже в новообразованных училищах не всегда хватало учителей для обучения всем запланированным в уставе наукам. Ocобенно сложно обстояло дело с преподаванием латинского языка, который, по отзыву профессора Х.А. Шлецера, «находился в большом пренебрежении» [20, л. 94 об.].

В отличие от систематических изложений, в которые помещали только информацию, непосредственно касающуюся учебных заведений, визитаторский журнал А.А. Прокоповича-Антонского дополнен интересными подробностями о природных особенностях края, занятиях местных жителей, постройках и сохранившихся исторических памятниках. Профессор осмотрел все имеющиеся на тот момент школы в губернии - гимназию, уездное и приходское училище в Рязани, а также девять малых народных училищ по уездам (в Пронске и Данкове к этому времени училища прекратили свое существование). Лучше всего оказалось состояние Зарайского, Касимовского и Скопинского училищ, которые визитатор предложил преобразовать в уездные.

Несомненно, визитаторские поездки приносили значительную пользу, а личное присутствие профессоров заставляло местную власть больше обращать внимание на нужды учебных заведений. Одним из самых серьезных недостатков, на который указывали визитаторы, было состояние училищных домов. Профессора характеризовали учебные постройки как «весьма тесные и неудобные» (см.:
[20, л. 91, 91 об., 101]), «весьма бедные» [21, л. 165 об.], «неприличные» [21, л. 167 об.], а некоторые московские училища были так тесны, что не хватало места для учащихся, «почему многие во время письменного класса принуждены писать или стоя, или на коленях» $[20$, л. 85]. Посещая училища Рязанской губернии, А.А. Прокопович-Антонский каждый раз пытался убедить местную власть найти новые помещения для школ. И его труды приносили результаты. В Касимове малое народное училище помещалось в ветхом деревянном общественном доме. Визитатор «согласил Градскую Думу, чтоб на большой улице, на том самом месте, которое по плану назначено возле собора для училища, выстроить дом, а прежний отделать для учителей. Место освящено, дом заложен и для учебных пособий граждане подписали более двухсот пятидесяти рублей» [14, с. 47]. В 1808 г. профессор М.М. Снегирев, осматривавший это училище, похвалил новое здание, найдя его «изрядным». Улучшений удалось добиться для Скопинского, Спасского и Раненбургского малых училищ, причем А.А. ПрокоповичАнтонский отметил, что «везде, где ни отвели при мне новые квартиры, гг. городничий и головы обещали не переменять их» [14, с. 49]. Сложная ситуация с помещением возникла и у Ярославской губернской гимназии. Здание Екатерининского дома призрения ближнего, где помещалось Ярославское главное народное училище, требовало капитального ремонта, поэтому учеников преобразованной 15 мая 1805 г. гимназии временно поместили в покои, предназначенные для Демидовского училища вышних наук [26]. После «поправок» гимназия вернулась в дом призрения, но проблемы со зданием сохранились: по словам визитаторов, помещение было «тесно и даже безобразно» [20, л. 91; 21, л. 163 об.].

Сами профессора, оценивая пользу от ежегодных визитаций, предлагали внести в процесс назначения обозрителей некоторые изменения. Так, А.А. Прокопович-Антонский выступал за то, чтобы не менять каждый год визитаторов по губерниям, а посылать одних и тех же, поскольку о «возвышении училищ визитаторы лучше судить будут, когда несколько раз сряду ездить станут по одним и тем же губерниям» [14, с. 51]. Профессор Х.А. Шле- 
цер, осматривавший в 1808 г. учебные заведения Костромской и Вологодской губерний, просил увеличить число визитаторов и посылать одновременно двух профессоров, особенно в отдаленные от Москвы губернии, «ибо часто при беспрестанно возобновляющемся единообразии визитатор утомляется, и теряет охоту делать нужные исследования», а так, пока «один делает обозрение училища, другой мог бы заняться разными учеными наблюдениями, от чего бы могла произойти двоякая польза» [20, л. 94 об.]. Однако и существующая практика назначения визитаторов была крайне обременительной как для университета, так и для самих профессоров, у которых эти поездки забирали много сил. Получалось, что весь период вакаций они проводили в дороге, преодолевая сложности путешествия, особенно если приходилось осматривать обширные и далекие от университетской столицы губернии. Печально закончилась визитация в Вологодскую губернию профессора И.А. Иде в 1806 г.: будучи не совсем здоровым, он отправился осматривать училища, а после возвращения скончался от легочной язвы [23, с. 221].

Совет университета старался обеспечить ежегодную визитацию всех губерний Московского учебного округа хотя бы в первое десятилетие действия нового устава. Однако это получалось не всегда. Анализируя попечительские отчеты, следует обратить внимание на то, что в 1807 и 1810 гг. количество визитаций резко сократилось: в 1807 г. профессором Х.А. Шлецером и директором московских училищ П.М. Дружининым были осмотрены только учебные заведения Ярославской и Тульской губерний соответственно, а в 1810 г. профессором М.Т. Каченовским - училища Калужской губернии. Возможно, это было связано с тем, что как раз в эти годы происходила смена попечителей: 29 июля 1807 г. умер М.Н. Муравьев, и на его место был назначен гр. А.К. Разумовский, которого, в свою очередь, 14 мая 1810 г. сменил П.И. Голенищев-Кутузов.

В 1811 г. визитаторов «для обозрения училищ Московского округа не было посылано потому что Его Превосходительство господин попечитель Московского округа Павел Иванович Голенищев-Кутузов с Высочайшего дозволения осматривал сам училища, со- стоящие в Тверской, Костромской и Ярославской губерниях» [13, л. 59]. Военные действия не позволили отправить профессоров-визитаторов и в 1812 г., а в следующие годы полных систематических инспекций не совершалось, университет ограничивался осмотром лишь нескольких губерний округа.

Результаты. В начале XIX в. в ходе образовательных реформ императора Александра I была создана единая система народного просвещения. Открывающиеся гимназии, уездные и приходские училища нуждались в постоянном внимании со стороны университетского начальства. Личные осмотры было невозможно заменить письменными донесениями директоров и смотрителей училищ. Благодаря визитаторским обозрениям университет, а через него и попечитель, и министр получали реальную информацию о состоянии училищ округа.

Естественно, что директора училищ, ожидая приезда университетского профессора, старались в самом выгодном свете представить положение учебного дела в гимназиях и уездных училищах. Да и за один-два дня, которые визитатор уделял для осмотра, вникнуть во все детали было достаточно сложно. Однако основную информацию о ходе учебного процесса, квалификации учителей, способностях учеников, необходимых нуждах в каждом конкретном училище они получали и ее тщательно фиксировали. Важно отметить, что, несмотря на естественные трудности таких поездок, профессора Московского университета старались посетить каждое учебное заведение тех губерний, куда были назначены для осмотра. Визитаторы старались не только подчеркнуть существующие успехи и недостатки, но и найти возможности для улучшения положения училища в будущем, что показывало их неформальное отношение к своим обязанностям. Особенно это касалось главной проблемы большинства учебных заведений - отсутствия удобных помещений для занятий. Профессора склоняли местных жителей к пожертвованиям в пользу училищ, заставляли губернское и уездное начальство искать удобные помещения, повышали общий интерес к образованию и, таким образом, приносили значительную пользу учебным заведениям. 


\section{ПРИЛОЖЕНИЕ}

Таблица визитаций по Московскому учебному округу в 1803-1810 гг.

Table of visits for the Moscow school district in 1803-1810

\begin{tabular}{|c|c|c|c|c|c|c|c|c|c|c|}
\hline \multirow{2}{*}{ Год } & \multicolumn{10}{|c|}{ Губерния Московского учебного округа } \\
\hline & $\begin{array}{c}\text { Влади- } \\
\text { мирская }\end{array}$ & $\begin{array}{c}\text { Вологод- } \\
\text { ская }\end{array}$ & $\begin{array}{c}\text { Калуж- } \\
\text { ская }\end{array}$ & $\begin{array}{c}\text { Костром- } \\
\text { ская }\end{array}$ & \begin{tabular}{|c|}
$\begin{array}{c}\text { Москов- } \\
\text { ская }\end{array}$ \\
\end{tabular} & Рязанская & $\begin{array}{c}\begin{array}{c}\text { Смолен- } \\
\text { ская }\end{array} \\
\end{array}$ & Тверская & Тульская & $\begin{array}{c}\text { Ярослав- } \\
\text { ская }\end{array}$ \\
\hline 1803 & $\begin{array}{l}\text { П.М. Дру- } \\
\text { жинин }\end{array}$ & \begin{tabular}{|l|} 
М.И. Па- \\
нкевич \\
\end{tabular} & И.А. Гейм & $\begin{array}{l}\text { М.И. Пан- } \\
\text { кевич } \\
\end{array}$ & \begin{tabular}{|l|} 
П.М. Дру- \\
жинин \\
\end{tabular} & $\begin{array}{l}\text { П.М. Дру- } \\
\text { жинин }\end{array}$ & \begin{tabular}{|l|} 
М.И. Нев- \\
зоров \\
\end{tabular} & $\begin{array}{l}\text { М.И. Не- } \\
\text { взоров }\end{array}$ & И.А. Гейм & $\begin{array}{l}\text { М.И. Па- } \\
\text { нкевич } \\
\end{array}$ \\
\hline 1804 & $\begin{array}{l}\text { М.М. Сне- } \\
\text { гирев }\end{array}$ & $\begin{array}{l}\text { Н.Е. Че- } \\
\text { репанов }\end{array}$ & $\begin{array}{l}\text { Н.Г. Ще- } \\
\text { голев }\end{array}$ & $\begin{array}{l}\text { Н.Е. Чере- } \\
\text { панов }\end{array}$ & - & $\begin{array}{l}\text { П.М. Дру- } \\
\text { жинин }\end{array}$ & - & $\begin{array}{l}\text { П.М. } \\
\text { Дружи- } \\
\text { нин } \\
\end{array}$ & $\begin{array}{l}\text { Н.Г. Ще- } \\
\text { голев }\end{array}$ & $\begin{array}{l}\text { П.М. Дру- } \\
\text { жинин }\end{array}$ \\
\hline 1805 & $\begin{array}{l}\text { А.А. Про- } \\
\text { копович- } \\
\text { Антонский }\end{array}$ & $\begin{array}{l}\text { А.М. Бря- } \\
\text { нцев }\end{array}$ & $\begin{array}{l}\text { П.А.Со- } \\
\text { хацкий }\end{array}$ & $\begin{array}{l}\text { В.К. Арше- } \\
\text { невский }\end{array}$ & $\begin{array}{l}\text { Училища г. } \\
\text { Москвыл- } \\
\text { М.И. Пан- } \\
\text { кевич, } \\
\text { И.Т. Буле, } \\
\text { Ф.Х. Рейн- } \\
\text { гард, } \\
\text { Л.А. Цве- } \\
\text { таев; } \\
\text { губернские } \\
\text { училища- } \\
\text { А.А. Про- } \\
\text { копович- } \\
\text { Антонский, } \\
\text { П.А. Со- } \\
\text { хацкий }\end{array}$ & $\begin{array}{l}\text { А.А. Про- } \\
\text { копович- } \\
\text { Антонский }\end{array}$ & И.А. Гейм & $\begin{array}{l}\text { И.А. Гейм, } \\
\text { М.И. Нев- } \\
\text { зоров }\end{array}$ & $\begin{array}{l}\text { П.А. Со- } \\
\text { хацкий }\end{array}$ & $\begin{array}{l}\text { В.К. Ар- } \\
\text { шенев- } \\
\text { ский }\end{array}$ \\
\hline 1806 & $\begin{array}{l}\text { В.К. Ар- } \\
\text { шеневский }\end{array}$ & И.А. Иде & $\begin{array}{l}\text { А.А. Про- } \\
\text { копович- } \\
\text { Антон- } \\
\text { ский }\end{array}$ & И.А. Гейм & \begin{tabular}{|l} 
П.А. Сохац- \\
кий, \\
Ф. Гольд- \\
бах, \\
Х.Л. Ште- \\
льцер, \\
Ф.Х. Рейн- \\
гард, \\
И.П. Вои- \\
нов, \\
Л.А. Цве- \\
таев \\
(только \\
училища \\
с. Москвы) \\
\end{tabular} & $\begin{array}{l}\text { В.К. Ар- } \\
\text { шеневский }\end{array}$ & $\begin{array}{l}\text { А.А. Про- } \\
\text { копович- } \\
\text { Антонский }\end{array}$ & $\begin{array}{l}\text { М.И. Пан- } \\
\text { кевич }\end{array}$ & $\begin{array}{l}\text { А.М. Бря- } \\
\text { нцев }\end{array}$ & И.А. Гейм \\
\hline 1807 & - & - & - & - & - & - & - & - & $\begin{array}{l}\text { П.М. Дру- } \\
\text { жинин }\end{array}$ & $\begin{array}{l}\text { Х.А. Шле- } \\
\text { цер }\end{array}$ \\
\hline 1808 & $\begin{array}{l}\text { М.М. Сне- } \\
\text { гирев }\end{array}$ & $\begin{array}{l}\text { Х.А. Шле- } \\
\text { цер }\end{array}$ & $\begin{array}{l}\text { П.М. Дру- } \\
\text { жинин }\end{array}$ & $\begin{array}{l}\text { Х.А. Шле- } \\
\text { цер }\end{array}$ & $\begin{array}{l}\text { И.Т. Буле, } \\
\text { Н.Е. Чере- } \\
\text { панов, } \\
\text { И.А. Дви- } \\
\text { губский }\end{array}$ & $\begin{array}{l}\text { М.М. Сне- } \\
\text { гирев }\end{array}$ & $\begin{array}{l}\text { М.Г. Гав- } \\
\text { рилов }\end{array}$ & $\begin{array}{l}\text { М.Г. Гав- } \\
\text { рилов }\end{array}$ & $\begin{array}{l}\text { П.М. Дру- } \\
\text { жинин }\end{array}$ & $\begin{array}{l}\text { А.А. Про- } \\
\text { копович- } \\
\text { Антон- } \\
\text { ский }\end{array}$ \\
\hline 1809 & - & $\begin{array}{l}\text { М.М. Сне- } \\
\text { гирев }\end{array}$ & $\begin{array}{l}\text { М.И. Пан- } \\
\text { кевич }\end{array}$ & $\begin{array}{l}\text { А.Ф. Мерз- } \\
\text { ляков }\end{array}$ & $\begin{array}{l}\text { А.А. Про- } \\
\text { копович- } \\
\text { Антонский, } \\
\text { Х.А. Шле- } \\
\text { цер, } \\
\text { И.А. Дви- } \\
\text { губский, } \\
\text { Л.А. Цве- } \\
\text { таев } \\
\text { (только } \\
\text { училища } \\
\text { г. Москвы) }\end{array}$ & - & - & - & $\begin{array}{l}\text { М.И.Пан- } \\
\text { кевич }\end{array}$ & $\begin{array}{l}\text { А.Ф. Мер- } \\
\text { зляков }\end{array}$ \\
\hline 1810 & - & - & $\begin{array}{l}\text { М.Т. Ка- } \\
\text { ченовский }\end{array}$ & - & - & - & - & - & - & - \\
\hline
\end{tabular}

Примечание. «-» обозначает, что визитации не проводились.

Note. "-" indicates that no visitations were made. 


\section{ПРИМЕЧАНИЕ}

1 Статья подготовлена в рамках проекта № 1-245/22 «Министерство народного просвещения в первой четверти XIX в.: формирование и развитие системы учебных заведений в Российской империи» при поддержке Фонда развития ПСТГУ.

The article is written within the framework of the project № 1-245/22 “The Ministry of Public Education in the First Quarter of the XIX Century: The Formation and Development of the System of Educational Institutions in the Russian Empire" supported by PSTGU Development Foundation.

\section{СПИСОК СОКРАЩЕНИЙ}

РГИА - Российский государственный исторический архив.

ЦГА г. Москвы - Центральный государственный архив г. Москвы.

\section{СПИСОК ЛИТЕРАТУРЫ}

1. Алешинцев, И. А. История гимназического образования в России (XVIII и XIX век) / И. А. Алешинцев. - СПб. : Изд-во О. Богданова, 1912. - 346 с.

2. Андреев, А. Ю. Московский университет в общественной и культурной жизни России начала ХІХ века / А. Ю. Андреев. - М. : Яз. рус. культуры, 2000. $-312 \mathrm{c}$.

3. Грачева, Ю. Е. Визитации попечителей учебных округов в начале ХІХ века / Ю. Е. Грачева // Манускрипт. - 2019. - Т. 12, вып. 10. - С. 46-52. - DOI: https://doi.org/10.30853/manuscript.2019.10.8.

4. Жуковская, Т. Н. Во главе училищ: административная деятельность дореформенного университета в России / Т. Н. Жуковская, Е. А. Калинина // Труды Института российской истории PAH. - 2015. - № 3. - С. 115-136.

5. Жуковская, Т. Н. Система инспектирования и контроля деятельности училищ светского и духовного ведомств в XIX веке: цели, формы, эффективность / Т. Н. Жуковская, Е. А. Калинина, К. С. Казакова // Труды Кольского научного центра РАН. - 2019. T. 10, № 2 (16). - C. 77-92. - DOI: https://doi.org/ 10.25702/KSC.2307-5252.2019.10.2.77-92.

6. Захаратос, Д. А. Московский учебный округ в 1804-1835 гг.: создание государственной системы образования, управление и подготовка педагогических кадров : дис. ... канд. ист. наук / Захаратос Дмитрий Андреевич. - М., 2003. - 206 с.

7. Книга исходящих дел канцелярии попечителя Московского учебного округа за 1805 год // ЦГА г. МосквЫ. - Ф. 459. - ОП. 11. - Д. 3. - 176 л.
8. Книга отходящих дел канцелярии попечителя Московского учебного округа за 1803 год // ЦГА г. Москвы. - Ф. 459. - Оп. 11. - Д. 1. - 45 л.

9. Кузбер, Я. Воспитание элит и народное образование в Российской империи XVIII - первой половины XIX века. Дискурс, законодательство, реальность / Я. Кузбер. - М. : Полит. энцикл., 2018. -613 с.

10. Наставление визитаторам Московского учебного округа. 1805 год // РГИА. - Ф. 733. Оп. 49. - Д. 295. - 19 л.

11. Наставление обозрителю училищ. 1804 год // РГИА. - Ф. 733. - Оп. 95. - Д. 179. - 224 л.

12. Отчет попечителя Московского учебного округа за 1803 год // РГИА. - Ф. 733. - Оп. 95. Д. $178 .-41$ л.

13. Отчет попечителя Московского учебного округа за 1811 год // РГИА. - Ф. 733. - Оп. 95. Д. $186 .-189$ л.

14. Отчет профессора Московского университета А.А. Прокоповича-Антонского о визитации училищ Рязанской губернии в 1805 году // Труды Рязанской ученой архивной комиссии. - 1888. - Т. 3, № 3. - С. 45-51.

15. Отчеты по Московскому учебному округу за 1803-1811 гг. // РГИА. - Ф. 733. - Оп. 95. Д. 178-186.

16. Периодическое сочинение о успехах народного просвещения. - 1804. - № 6. - 102 с.

17. Письмо министра народного просвещения к попечителю Виленского учебного округа от 5 мая 1803 года // Сборник материалов для истории просвещения в России, извлеченных из Архива Министерства народного просвещения. Т. 2. - СПб. : Изд. М-ва нар. просвещения, 1897. - С. 215-216.

18. Предварительные правила народного просвещения // Сборник постановлений по Министерству народного просвещения. Т. 1. - 2-е изд. - СПб. : Тип. В.С. Балашева, 1875. - С. 13-21.

19. Рождественский, С. В. Исторический обзор деятельности Министерства народного просвещения / С. В. Рождественский. - СПб. : Изд. М-ва нар. просвещения, 1902. - 785 с.

20. Систематическое извлечение из визитаторских донесений на 1808 год // РГИА. - Ф. 732. Оп. 1. - Д. 154. - 164 л.

21. Систематическое извлечение из визитаторских донесений на 1809 год // РГИА. - Ф. 733. Оп. 95. - Д. 184. - 183 л.

22. Сухомлинов, М. И. Исследования и статьи по русской литературе и просвещению. В 2 т. Т. 1 / М. И. Сухомлинов. - СПб. : А.С. Суворин, 1889. $686 \mathrm{c}$.

23. Университет в Российской империи XVIII - первой половины XIX века / под общ. ред. А. Ю. Андреева, С. И. Посохова. - М. : Рос. полит. энцикл., 2012. -671 с. 
24. Устав Императорских Московского, Харьковского и Казанского университетов. 5 ноября 1804 года // Сборник постановлений по Министерству народного просвещения. Т. 1. - 2-е изд. - СПб. : Тип. В.С. Балашева, 1875. - С. 295-331.

25. Устав учебных заведений, подведомых университетам. 5 ноября 1804 года // Сборник постановлений по Министерству народного просвещения. Т. 1. - 2-е изд. - СПб. : Тип. В.С. Балашева, 1875. - C. 331-368.

26. Фирсов, Д. Е. К вопросу размещения Ярославской губернской гимназии / Д. Е. Фирсов. - Электрон. текстовые дан. - Режим доступа: http:// www.gvw-rggu.narod.ru/section/section3/stati2012/ firsov.htm (дата обращения: 25.11.2019).

\section{REFERENCES}

1. Aleshintsev I.A. Istoriya gimnazicheskogo obrazovaniya $v$ Rossii (XVIII i XIX vek) [The History of Gymnasium Education in Russia (18 $8^{\text {th }}$ and $19^{\text {th }}$ Century)]. Saint Petersburg, Izd-vo O. Bogdanova, 1912.346 p.

2. Andreev A.Yu. Moskovskiy universitet v obshchestvennoy i kulturnoy zhizni Rossii nachala XIX veka [Moscow University in the Social and Cultural Life of Russia in the Early $19^{\text {th }}$ Century]. Moscow, Yazyki russkoy kultury Publ., 2000. 312 p.

3. Gracheva Yu.E. Vizitatsii popechiteley uchebnykh okrugov v nachale XIX veka [Visitations of Educational Districts' Trustees at the Beginning of the $19^{\text {th }}$ Century]. Manuskript [Manuscript], 2019, vol. 12, iss. 10, pp. 46-52. DOI: 10.30853/ manuscript.2019.10.8.

4. Zhukovskaya T.N., Kalinina E.A. Vo glave uchilishch: administrativnaya deyatelnost doreformennogo universiteta $v$ Rossii [At the Head of Schools: An Administrative Activities of Prereform University in Russia]. Trudy Instituta rossiyskoy istorii RAN [Proceedings of the Institute of Russian History of the Russian Academy of Sciences], 2015, no. 3, pp. 115-136.

5. Zhukovskaya T.N., Kalinina E.A., Kazakova K.S. Sistema inspektirovaniya i kontrolya deyatelnosti uchilishch svetskogo i dukhovnogo vedomstv v XIX veke: tseli, formy, effektivnost [The System of Inspection and Control of the Activities of Schools of Secular and Spiritual Departments in the $19^{\text {th }}$ Century: Goals, Forms, Effectiveness]. Trudy Kolskogo nauchnogo tsentra RAN [Russian Academy of Sciences Transactions Kola Science Centre], 2019, vol. 10, no. 2 (16), pp. 77-92. DOI: 10.25702/KSC.23075252.2019.10.2.77-92.

6. Zakharatos D.A. Moskovskiy uchebnyy okrug v 1804-1835 gg.: sozdanie gosudarstvennoy sistemy obrazovaniya, upravlenie $i$ podgotovka pedagogicheskikh kadrov: dis. ... kand. ist. nauk [Moscow School District in 1804-1835: Creation of a State Education System, Management and Training of Teaching Staff]. Moscow, 2003. 206 p.

7. Kniga iskhodyashchikh del kantselyarii popechitelya Moskovskogo uchebnogo okruga za 1805 god [Outgoing Affairs Book of the Office of the Moscow School District Tustee for 1805]. Ts $G A$ g. Moskvy [Central State Archive of Moscow], F. 459, Op. 11, D. 3. 1761.

8. Kniga otkhodyashchikh del kantselyarii popechitelya Moskovskogo uchebnogo okruga za 1803 god [Departing Affairs Book of the Office of the Moscow School District Tustee for 1803]. TsGA g. Moskvy [Central State Archive of Moscow], F. 459, Op. 11, D. 1.451.

9. Kuzber Ya. Vospitanie elit $i$ narodnoe obrazovanie $v$ Rossiyskoy imperii XVIII - pervoy poloviny XIX veka. Diskurs, zakonodatelstvo, realnost [Education of Elites and Public Education in the Russian Empire of the $18^{\text {th }}-$ Early $19^{\text {th }}$ Century. Discourse, Legislation, Reality]. Moscow, Politicheskaya entsiklopediya Publ., 2018. 613 p.

10. Nastavlenie vizitatoram Moskovskogo uchebnogo okruga. 1805 god [Manual for Visitors to the Moscow School District. 1805]. RGIA [Russian State Historical Archive], F. 733, Op. 49, D. 295. 191.

11. Nastavlenie obozritelyu uchilishch. 1804 god [Instruction for a School Visitor. 1804]. RGIA [Russian State Historical Archive], F. 733, Op. 95, D. 179, 2241.

12. Otchet popechitelya Moskovskogo uchebnogo okruga za 1803 god [Report of the Moscow School District Trustee for 1803]. RGIA [Russian State Historical Archive], F. 733, Op. 95, D. 178. 411.

13. Otchet popechitelya Moskovskogo uchebnogo okruga za 1811 god [Report of the Moscow School District Trustee for 1811 year]. RGIA [Russian State Historical Archive], F. 733, Op. 95, D. 186. 1891.

14. Otchet professora Moskovskogo universiteta A.A. Prokopovicha-Antonskogo o vizitatsii uchilishch Ryazanskoy gubernii v 1805 godu [Report of Professor of Moscow University A.A. Prokopovich-Antonsky on the Visitation of the Schools of the Ryazan Province in 1805]. Trudy Ryazanskoy uchenoy arkhivnoy komissii, 1888, vol. 3, no. 3, pp. 45-51.

15. Otchety po Moskovskomu uchebnomu okrugu za 1803-1811 gg. [Reports on the Moscow School District for 1803-1811]. RGIA [Russian State Historical Archive], F. 733, Op. 95, D. 178-186.

16. Periodicheskoe sochinenie o uspekhakh narodnogo prosveshcheniya [Periodic Essay on the Success of Public Education], 1804, no. 6. 102 p.

17. Pismo ministra narodnogo prosveshcheniya $\mathrm{k}$ popechitelyu Vilenskogo uchebnogo okruga ot 5 maya 1803 goda [Letter of the Minister of 
Education to the Vilnius School District Trustee of May 5, 1803]. Sbornik materialov dlya istorii prosveshcheniya $v$ Rossii, izvlechennykh iz arkhiva ministerstva narodnogo prosveshcheniya. T. 2 [Collection of Materials for the History of Education in Russia Extracted From the Archives of the Ministry of Education. Vol. 2]. Saint Petersburg, Izdanie Ministerstva narodnogo prosveshcheniya, 1897, pp. 215-216.

18. Predvaritelnye pravila narodnogo prosveshcheniya [Preliminary Rules for Public Education]. Sbornik postanovleniy po Ministerstvu narodnogo prosveshcheniya. T. 1 [Collection of Decisions on the Ministry of Education. Vol. 1]. Saint Petersburg, Tipografiya V.S. Balasheva, 1875, pp. 13-21.

19. Rozhdestvenskiy S.V. Istoricheskiy obzor deyatelnosti Ministerstva narodnogo prosveshcheniya [Historical Review of the Activities of the Ministry of Education]. Saint Petersburg, Izdanie Ministerstva narodnogo prosveshcheniya, 1902. $785 \mathrm{p}$.

20. Sistematicheskoe izvlechenie iz vizitatorskikh doneseniy na 1808 god [Systematic Extraction of Visitor Reports for 1808]. RGIA [Russian State Historical Archive], F. 732, Op. 1, D. 154. 1641.

21. Sistematicheskoe izvlechenie iz vizitatorskikh doneseniy na 1809 god [Systematic Extraction of Visitor Reports for 1809]. RGIA [Russian State Historical Archive], F. 733, Op. 95, D. 184. 1831.

22. Sukhomlinov M.I. Issledovaniya i statyi po russkoy literature $i$ prosveshcheniyu. $V 2$ t. T. 1
[Studies and Articles on Russian Literature and Education. In 2 Vols. Vol. 1]. Saint Petersburg, A.S. Suvorin Publ., 1889. 686 p.

23. Andreev A.Yu., Posokhov S.I., eds. Universitet v Rossiyskoy imperii XVIII-pervoy poloviny XIXveka [University in the Russian Empire of the $18^{\text {th }}-$ First Half of the $19^{\text {th }}$ Century]. Moscow, Rossiyskaya politicheskaya entsiklopediya Publ., 2012.671 p.

24. Ustav Imperatorskikh Moskovskogo, Kharkovskogo i Kazanskogo universitetov. 5 noyabrya 1804 goda [Charter of the Imperial Moscow, Kharkov and Kazan Universities. November 5, 1804]. Sbornik postanovleniy po Ministerstvu narodnogo prosveshcheniya. T. 1 [Collection of Decisions on the Ministry of Education. Vol. 1]. Saint Petersburg, Tipografiya V.S. Balasheva, 1875, pp. 295-331.

25. Ustav uchebnykh zavedeniy, podvedomykh universitetam. 5 noyabrya 1804 goda [Charter of Education Institutions Subordinate to Universities. November 5, 1804]. Sbornik postanovleniy po Ministerstvu narodnogo prosveshcheniya. T. 1 [Collection of Decisions on the Ministry of Education. Vol. 1]. Saint Petersburg, Tipografiya V.S. Balasheva, 1875. vol. 1, pp. 331-368.

26. Firsov D.E. K voprosu razmeshcheniya Yaroslavskoy gubernskoy gimnazii [On the Issue of Placement of the Yaroslavl Provincial Gymnasium]. URL: http://www.gvw-rggu.narod.ru/ section/section3/stati2012/firsov.htm/ (accessed 25 November 2019).

\section{Information About the Author}

Julija E. Gracheva, Candidate of Sciences (History), Associate Professor, Department of Russian History, St. Tikhon's Orthodox University, Novokuznetskaya St., 23-5A, 115184 Moscow, Russian Federation, g.yuliya@mail.ru, https://orcid.org/0000-0002-2220-9361

\section{Информация об авторе}

Юлия Евгеньевна Грачева, кандидат исторических наук, доцент кафедры истории России, Православный Свято-Тихоновский гуманитарный университет, ул. Новокузнецкая, 23-5А, 115184 г. Москва, Российская Федерация, g.yuliya@mail.ru, https://orcid.org/0000-0002-2220-9361 